Фармакологічні дослідження біологічно активних речовин

Pharmacological researches of biologically active substances

Рекомендована д. біол. наук, профр. Л. С. Фірою

УДК 615.322:615.451.16:615.011.5

DOI

\title{
ВИЗНАЧЕННЯ АНТИОКСИДАНТНОЇ АКТИВНОСТІ ЗАБАРВЛЕНИХ РОСЛИННИХ EKCTPAKTIB IN VITRO
}

\author{
(ㄷ Г. Р. Ламазян, І. М. Ситник, П. А. Черновол, І. С. Чекман, М. В. Хайтович \\ Національний медичний університет імені О. О. Богомольця
}

\begin{abstract}
Резюме: досліджено антиоксидантну активність (АОА) рослинних екстрактів на моделі інгібування супероксидрадикала in vitro 3 модифікаціями. Оптичну густину екстрактів, у їх масових концентраціях 0,5 мг/мл, 0,5×10-3, $0,5^{\times} 10^{-6}$ мг/мл, реєстрували спектросротометрично при довжині хвилі 340 нм на 0 хв та на 10 хв. Екстракти Hypericum perforatum (L.) та Citrullus colocynthis (L.) Shrad. показали наявність АOА в діапазоні всіх концентрацій. На 10 хв значення АОА екстрактів зменшувалось приблизно вдвічі при концентраціях $0,5^{\times} 10^{-3}$ мг/мл і 0,5×10-6 мг/мл; при концентрації 0,5 мг/мл - у 2,5 раза в Citrullus colocynthis (L.) Shrad., та незначне зменшення значення AOA при цій же концентрації спостерігали в Hypericum perforatum (L.). AOA Hypericum perforatum (L.) збільшувалась зі зростанням концентрації, тоді як для Citrullus colocynthis (L.) Shrad. прямопропорційної залежності «концентраціяактивність» не відмічали, максимальну АОА останнього реєстрували при концентрації 0,5×10-3 мг/мл.
\end{abstract}

Ключові слова: антиоксидантна активність, екстракти, Hypericum perforatum (L.), Citrullus colocynthis (L.) Shrad., активні фрорми кисню, антиоксиданти.

Вступ. На сьогодні доведено взаємозв'язок між вільнорадикальним окисненням та розвитком більшості патологічних процесів - ендокринологічних та серцево-судинних захворювань тощо. Сучасні умови життя, негативний вплив фракторів зовнішнього середовища, психоемоційне напруження, генетичні фрактори - все це $є$ передумовою для порушення окисно-відновної рівноваги в організмі. Вирішальну роль у даному відношенні мають активні фрорми кисню (АФК), до яких відносять радикал-супероксид аніон $\left(\mathrm{O}_{2}\right)^{-}$, синглетний кисень $\left({ }^{1} \mathrm{O}_{2}\right)$, пероксид водню $\left(\mathrm{H}_{2} \mathrm{O}_{2}\right)$, пергідроксильний радикал $\left(\mathrm{HO}_{2}^{\bullet}\right)$, пероксинітрит (ONOO-), оксид нітрогену (NO) та найбільш активний - гідроксил радикал (НО•), що у надлишку пошкоджують біомолекули, включно білки, ліпіди, РНК і ДНК. Слід зазначити, що супероксид аніон не $€$ найреактивнішим, проте здатний ініціювати генерацію найбільш активних АФК, таких як НО• та ONOO-, зумовлюючи тим самим розвиток окисного стресу (OC) $[1,2]$.

Останнім часом активно вивчають антиоксидантні властивості лікарської рослинної сировини (ЛРС) у попередженні та корекції ОС [3].

Як відомо, ЛРС є джерелом поліфренольних сполук - сильних природних антиоксидантів, які пригнічують ланцюгові реакції вільнорадикального окиснення через гальмування прооксидантних фрерментів, утворення металічних хелатів або нейтралізацію радикалів [1, 2, 3].

Метою даної роботи було дослідження антиоксидантної активності (АОА) рослинних екстрактів Hypericum perforatum (L.) та Citrullus colocynthis (L.)
Shrad. на моделі інгібування супероксид-радикала in vitro.

Методи дослідження. Як об'єкт дослідження використовували сухий екстракт Hуреricum perforatum (L.) та сухий екстракт Citrullus colocynthis (L.) Shrad.

Сухий екстракт Citrullus colocynthis (L.) Shrad. отримували на кафедрі фармакогнозії та ботаніки Національного медичного університету імені О. О. Богомольця $[4,5]$. Сухий екстракт Нуреricum perforatum (L.) отримували 3 препарату «Депривіт» (у перерахунку на 0,5 \% екстракту) виробництва ВАТ «Київський вітамінний завод». Досліджувані екстракти подрібнювали до порошкової маси для точності розрахунку необхідної концентрації.

Попередньо приготовлений водний розчин екстрактів (5 мг відповідного екстракту розчиняли в 10 мл дистильованої води) розводили до відповідних масових концентрацій 0,5 мг/мл, 0,5×10-3,

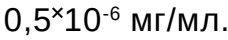

AOA рослинних екстрактів H. perforatum (L.) та C. colocynthis (L.) Shrad вивчали на базі НДІ експериментальної та клінічної медицини НМУ імені О. О. Богомольця.

Визначення АОА проводили згідно з методикою [6] 3 нашими модифікаціями. За допомогою методу спектрофотометрії реєстрували зміни оптичної густини досліджуваних екстрактів і визначали AOA за ступенем інгібування супероксидрадикала.

Дана методика була обрана 3 метою вивчення впливу рослинних екстрактів на початкові стадії

ISSN 2312-0967. Фармацевтичний часопис. 2015. № 4 
Фармакологічні дослідження біологічно активних речовин Pharmacological researches of biologically active substances

ОС, тобто утворення супероксид-радикала. Тому методика неферментного ініціювання вільнорадикального окиснення in vitro на моделі гальмування тіобарбітурат-активних продуктів - кінцевих продуктів ОС [7] нами не розглядалась.

Як систему, яка продукує супероксид-радикал, брали автоокиснення адреналіну в адренохром у лужному середовищі. Розчин адреналіну готували на бідистильованій воді, використовуючи 0,1\% розчин адреналіну гідротартрату в перерахунку на 40,5 мг адреналіну. До мірної колби на 20 мл вносили 4,5 мл 0,1\% розчину адреналіну і додавали 10 мл бідистильованої води, після чого по 0,5-1 мл 0,1н НCl, доводили $\mathrm{pH}$ до 2.0, потім бідистилятом доводили об'єм до 20 мл.

До кювети біохімічного аналізатора SINNOWA BS3000М, вносили 0,5 мл 0,15 М карбонатного буфера pH 10,2, який містить 500 мг трилону Б на 1 л об'єму. Після цього вносили досліджувані екстракти в масо-

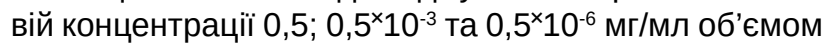
0,125 мл. Реакцію запускали внесенням 0,1 мл розчину адреналіну. Оптичну густину визначали при довжині хвилі 340 нм проти карбонатного буфера.

Експериментально було підтверджено, що утворення адренохрому в реакції автоокиснення адреналіну є максимальним в діапазоні хвиль 330-365 нм [8]. Інтенсивність наростання оптичної густини значно вища при 340 нм - середній величині в даному діапазоні, ніж при 480 нм, як зазначалось в методі [6].

На відміну від моделі, зазначеної вище, у роботі були поставлені три проби: дослідна, в яку вносили досліджувану речовину; контрольна, що не містила досліджуваної речовини; і холоста - буферований розчин екстрактів без додавання адреналіну з метою врахування впливу власного забарвлення екстрактів, котрі поглинають певну довжину хвилі у видимій частині спектра.

Антиоксидантну активність досліджуваних екстрактів виражали у відсотках інгібування автоокиснення адреналіну та розраховували за фрормулою:

$$
A O A=\frac{D \kappa-(D \partial-D x)}{D \kappa} \times 100
$$

де АОА - \% антиоксидантної активності;

$\mathrm{D}_{\text {к }}$ - оптична густина контрольної проби;

$\mathrm{D}_{\text {д }}$ - оптична густина дослідної проби;

$\mathrm{D}_{\mathrm{x}}^{\mathrm{A}}$ - оптична густина холостої проби (без внесення адреналіну).

Значення АОА фріксували відразу після додавання розчину адреналіну гідротартрату та на десятій хвилині її експозиції.

Математичну обробку отриманих даних проводили методами варіаційної статистики з використанням однофракторного дисперсійного аналізу ANOVA, використовуючи критерій Даннета.

Результати й обговорення. Виявлено, що при внесенні рослинних екстрактів до модельної тест-системи достовірно знижується оптична густина порівняно з контрольним дослідом. Для екстракту $H$. perforatum даний показник знижувався у 24 рази на «0» хвилині та у 7,9 раза через 10 хв при концентрації 0,5 мг/мл. Для екстракту C. colocynthis найменші значення оптичної густини реєстрували при концентрації 0,5×10-3 мг/ мл, що у 8,8 раза та у 1,7 раза менше, порівняно 3 контролем на «0» та «10» хвилині відповідно (таблиця 1, 2).

Досліджувані екстракти виявляли високу АОА в діапазоні всіх концентрацій, попереджуючи утворення супероксид-радикала in vitro. Дещо вищою вона була у $H$. perforatum порівняно з C. colocynthis. Слід зазначити, що АОА екстрактів залежить від їх концентрацій. Для H. perforatum (L.) ця залежність $\epsilon$ прямопропорційною: із збільшенням концентрації екстракту зростала і його АОА. Найвищі значення AOA для Н. perforatum (95,77\%) виявлено при концентрації 0,5 мг/мл. C. colocynthis виявляла максимальну АOA (88,62 \%) при концентрації $0,5^{\times} 10^{-3}$ мг/мл (рис.1).

Таблиця 1. Зміни оптичної густини при внесенні досліджуваних екстрактів до модельної тест-системи на «0» хвилині експозиції

\begin{tabular}{|c|c|c|c|c|c|c|c|c|c|}
\hline \multirow{3}{*}{ Екстракт } & \multicolumn{9}{|c|}{ Концентрація (мг/мл) } \\
\hline & \multicolumn{3}{|c|}{0,5} & \multicolumn{3}{|c|}{$0,5^{\times} 10^{-3}$} & \multicolumn{3}{|c|}{$0,5^{\times} 10^{-6}$} \\
\hline & $\mathrm{D}_{0}$ & $\mathrm{D}_{\mathrm{x}}$ & $\mathrm{AOA}, \%$ & $\mathrm{D}_{0}$ & $D_{x}$ & $\mathrm{AOA}, \%$ & $\mathrm{D}_{0}$ & $D_{x}$ & AOA, $\%$ \\
\hline Контроль & $\begin{array}{c}0,0652 \pm \\
0,0025 \\
\end{array}$ & - & - & - & - & - & - & - & - \\
\hline $\begin{array}{c}\text { Hypericum } \\
\text { perforatum (L.) }\end{array}$ & $\begin{array}{l}0,4063 \pm \\
0,0039 *\end{array}$ & $\begin{array}{c}0,4035 \pm \\
0,0032 \\
\end{array}$ & 95,78 & $\begin{array}{l}0,0724 \pm \\
0,0042^{\star}\end{array}$ & $\begin{array}{c}0,0678 \pm \\
0,0044\end{array}$ & 92,91 & $\begin{array}{l}0,0655 \pm \\
0,0047^{*}\end{array}$ & $\begin{array}{c}0,0586 \pm \\
0,0032\end{array}$ & 89,46 \\
\hline $\begin{array}{l}\text { Citrullus } \\
\text { Colocynthis } \\
\text { (L.) Shrad. }\end{array}$ & $\begin{array}{l}0,1386 \pm \\
0,0034 *\end{array}$ & $\begin{array}{c}0,1127 \pm \\
0,0032\end{array}$ & 60,39 & $\begin{array}{l}0,0665 \pm \\
0,0042^{\star}\end{array}$ & $\begin{array}{c}0,0591 \pm \\
0,0023\end{array}$ & 88,62 & $\begin{array}{l}0,0655 \pm \\
0,0042^{\star}\end{array}$ & $\begin{array}{c}0,0558 \pm \\
0,0023\end{array}$ & 85,21 \\
\hline
\end{tabular}

Примітка: *p<0,01 відносно до контролю (порівняно з різницею $D_{0}-D_{x}$ ).

ISSN 2312-0967. Pharmaceutical review. 2015. № 4 
Фармакологічні дослідження біологічно активних речовин Pharmacological researches of biologically active substances

Таблиця 2. Зміни оптичної густини при внесенні досліджуваних екстрактів до модельної тест-системи на «10» хвилині експозиції

\begin{tabular}{|c|c|c|c|c|c|c|c|c|c|}
\hline \multirow{3}{*}{ Екстракт } & \multicolumn{9}{|c|}{ Концентрація (мг/мл) } \\
\hline & \multicolumn{3}{|c|}{0,5} & \multicolumn{3}{|c|}{$0,5^{\times} 10^{-3}$} & \multicolumn{3}{|c|}{$0,5^{\times} 10^{-6}$} \\
\hline & $D_{10}$ & $D_{x}$ & $\mathrm{AOA}, \%$ & $D_{10}$ & $D_{x}$ & $\mathrm{AOA}, \%$ & $D_{10}$ & $D_{x}$ & $\mathrm{AOA}, \%$ \\
\hline Контроль & $\begin{array}{c}0,1848 \pm \\
0,0223\end{array}$ & - & - & - & - & - & - & - & - \\
\hline $\begin{array}{c}\text { Hypericum } \\
\text { perforatum (L.) }\end{array}$ & $\begin{array}{l}0,4268 \pm \\
0,0082^{\star}\end{array}$ & $\begin{array}{c}0,4035 \pm \\
0,0032 \\
\end{array}$ & 87,40 & $\begin{array}{l}0,1733 \pm \\
0,0064^{*}\end{array}$ & $\begin{array}{c}0,0678 \pm \\
0,0044\end{array}$ & 42,95 & $\begin{array}{l}0,1659 \pm \\
0,0039 *\end{array}$ & $\begin{array}{r}0,0586 \pm \\
0,0032\end{array}$ & 41,96 \\
\hline $\begin{array}{c}\text { Citrullus } \\
\text { Colocynthis (L.) } \\
\text { Shrad. }\end{array}$ & $\begin{array}{c}0,2528 \pm \\
0,0111\end{array}$ & $\begin{array}{c}0,1127 \pm \\
0,0032\end{array}$ & 24,25 & $\begin{array}{l}0,1690 \pm \\
0,0054^{*}\end{array}$ & $\begin{array}{c}0,0591 \pm \\
0,0023\end{array}$ & 40,58 & $\begin{array}{l}0,1660 \pm \\
0,0066^{*}\end{array}$ & $\begin{array}{l}0,0558 \pm \\
0,0023\end{array}$ & 40,41 \\
\hline
\end{tabular}

Примітка: *p<0,01 відносно контролю (порівняно з різницею $\mathrm{D}_{10}-\mathrm{D}_{\mathrm{x}}$ ).

Значення показників оптичної густини екстрактів на десятій хвилині експозиції свідчать, що з часом їх АОА знижувалась: незначне зменшення спостерігали при концентрації 0,5 мг/мл та приблизно вдвічі при концентраціях $0,5^{\times} 10^{-3} \mathrm{Mr} / \mathrm{M} л$ і $0,5^{\times} 10^{-6} \mathrm{Mr} / \mathrm{M} л$ y H. perforatum (L.), у C. colocynthis (L.) Shrad. - y 2,5 раза - при першій концентрації та приблизно вдвічі - при двох останніх концентраціях $0,5^{\times} 10^{-3}$ мг/мл і $0,5^{\times} 10^{-6} \mathrm{мг/мл.}$

Зниження активності рослинних екстрактів 3 часом можна пояснити їх багатокомпонентним складом і взаємним впливом біологічно активних речовин, які можуть бути як антагоністами, так і синергістами. Разом 3 тим, наявність відновників різної хімічної природи зумовлює складність кількісної оцінки АОА для рослинної сировини.

Відомо, що антиоксидантний та антирадикальний ефекти ЛРС досягаються за рахунок наявності неензиматичних молекул, представлених переважно поліфренольними сполуками - фрлавоноїдами, френолкарбоновими кислотами, катехінами, стільбена- ми тощо. Фітохімічний скринінг рослинної сировини C. colocynthis показав наявність фенольних сполук, фенолкарбонових кислот (хлорогенова кислота), фрлавоноїдів (ізосапонарин, ізовітексин та ізооріентин3'-О-метил етер) [9, 10], високий вміст танінів [11].

H. perforatum містить дубильні речовини, флавоноїди (гіперозид, рутин, кверцетин, ізокверцитрин, мірецетин, лейкоантоціани), антраценпохідні (гіперицин, псевдогіперицин, гіперин, сррангулаемодинантранол), фрлороглюцини (гіперфорин), вітамін С, незначні кількості френолкарбонових кислот -хлорогенової кислоти та сліди ксантонів [7].

За рахунок наявності ряду фенольних сполук, ЛРС має широкий спектр фрармакологічної активності, включно протизапальну, противірусну, протимікробну, гіпохолестеринемічну, гіпоглікемічну, судиннорелаксуючу, регенераторну, жовчовивідну та секреторну дію [7].

Антиоксиданти фенольної природи захоплюють вільні радикали, надаючи їм водень, і тим самим продукують стабільні антиоксидантні радикали з низьким

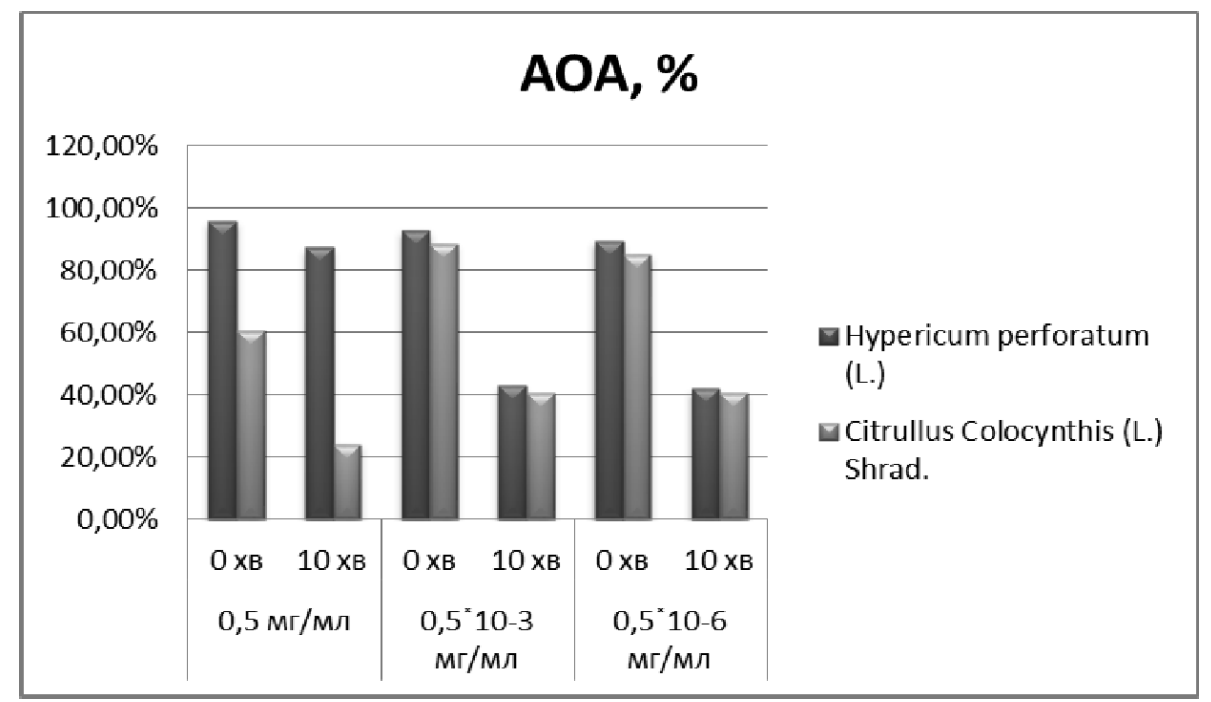

Рис. 1. АОА досліджуваних екстрактів залежно від часу та концентрації.

ISSN 2312-0967. Фармацевтичний часопис. 2015. № 4 
відновним потенціалом (менш як 0,5 В) [12], інактивують АФК, впливаючи на роботу фрерментних систем, блокуючи ксантиноксидазу, НАДФН-оксидазу, циклооксигеназу, протеїнкіназу С тощо [1, 3, 7]. На молекулярному рівні, природні антиоксиданти діють на специфічні сигнальні шляхи, гальмуючи транскрипційні фрактори NFkB, Nrf2, p62 протеїну, які беруть участь в регуляції антиоксидантних фрерментів та автофрагії $[3,13]$.

Активність цих сполук залежить від розміщення функціональних груп, а конфрігурація і загальна кількість гідроксильних груп визначають механізми антиоксидантної активності [7].

Активація клітинних захисних механізмів рослинними поліфенолами значно зменшує прояви ОС. Так, ряд епідеміологічних та експериментальних дослі- джень вказують на те, що регулярна дія природних поліфренолів покращує якість життя пацієнтів при цукровому діабеті, хворобі Альцгеймера, артеріальній гіпертензії, метаболічному синдромі [3, 13].

Висновки. 1. Встановлено, що рослинні екстракти H. perforatum (L.) ma C. colocynthis (L.) Shrad виявляють АОА в діапазоні всіх концентрацій.

2. Активність екстрактів залежить від концентрації. Найвищі значення АОА для $H$. perforatum $(95,77 \%)$ виявлено при концентрації 0,5 мг/мл, a для C. colocynthis $(88,62 \%)$ - при концентрації $0,5^{\times} 10^{-3} \mathrm{мг} / \mathrm{мл}$.

3. Виявлено зниження AOA H. perforatum (L.) ma C. colocynthis (L.) Shrad 3 часом (на 10 хв експозиції), що може бути зумовлено взаємним впливом комплексу біологічно активних речовин екстрактів.

\section{Список літератури}

1. Significance of antioxidant potential of plants and its relevance to therapeutic applications / D. M. Kasote, S. S. Katyare, M. V. Hegde [et al.] // International Journal of Biological Sciences. - 2015. - Vol. 11, № 8. - P. 982-991.

2. Chemical and molecular mechanisms of antioxidants: experimental approaches and model systems/ Jian-Ming Lba, P. H. Lin, Q. Yao [at al.] // J. Cell. Mol. Med. - 2010. Vol.14, № 4. - P.840-860.

3. Upadhyay S. Role of polyphenols and other phytochemicals on molecular signaling / S. Upadhyay, M. Dixit // Oxidative Medicine and Cellular Longevity. 2015. - Vol. 2015. - [Електронний ресурс].- Режим доступу: http://dx.doi.org/10.1155/2015/504253

4. Практикум по фрармакогнозии: учеб. пособие для студ. вузов / [Ковалев В. Н., Попова Н. В.и др.]; под общ. ред. В. Н. Ковалева.-Х. : Изд-во НФаУ; Золотые страницы, 2003.- С. 64-65.

5. Тихонов А. И. Технология лекарств: учеб. для фрармац. вузов и фрак. / А. И. Тихонов, Т. Г. Ярных; пер. с укр. - Х. : Изд-во НФаУ; Золотые страницы, 2002. C. $331-337$.

6. Моргунцова С. А. Антиоксидантна активність S-заміщених хіназоліну в умовах інгібування супероксидрадикала in vitro / С. А. Моргунцова, І. Ф. Бєленічев // Вісник Запорізького національного університету. - 2009. - № 1. - С. 161-165.

7. Impact of origin and biological source on chemical composition, anticholinesterase and antioxidant properties of some St. John's Wort species (Hypericum

spp., Hypericaceae) from the central Balkans / B. Bohin, N. Kladar, N. Grujiж [et al.] // Molecules. - 2013. - № 18. P.11733-11750.

8. Сирота Т. В. Новый подход в исследовании реакции автоокисления адреналина: возможность полярографического определения активности супероксиддисмутазы и антиоксидантных свойств различных препаратов / Т. В. Сирота // Биомедицинская химия. - 2012. - Т. 58, вып. 1. - С. 77-87.

9. Jayaraman R. Evaluation of Citrullus colocynthis fruits on in vitro antioxidant activity and in vivo DEN/PB induced hepatotoxicity / R. Jayaraman, Christina A.J.M. // IJARNP. - 2013. - Vol. 6, № 1. - P. 1-9.

10. Flavone c-glycosides and cucurbitacin glycosides from citrullus colocynthis / A. Delazar, S. Gibbons, A. R. Kosari [et al.] // DARU. - 2006. - Vol.14, № 3. - P. 109-114.

11. Igwenyi I. O. Phytochemical Analysis and Vitamin Composition of Irvigna Gabonesis and Citrullus Colocynthis I I. O. Igwenyi // IOSR-JPBS. - 2014. - Vol. 9, № 3. - P. 37-40. 12. Про- та антиоксидантна системи і патологічні процеси в організмі людини / О. Г. Резніков, О. М. Полумбрик, Я. Г. Бальон [та ін.] // Вісн. НАН України. 2014. - № 10. - C.17-29.

13. Polyphenol stilbenes: molecular mechanisms of defence against o xidative stress and aging-related diseases / M. Reinisalo, A.Kerlund, A. Koskela [et al.] // Oxidative Medicine and Cellular Longevity. - 2015. - Vol. 2015. [Електронний ресурс].- Режим доступу: http://dx.doi. org/10.1155/2015/340520 
Фармакологічні дослідження біологічно активних речовин

Pharmacological researches of biologically active substances

\title{
ОПРЕДЕЛЕНИЕ АНТИОКСИДАНТНОЙ АКТИВНОСТИ ОКРАШЕННЫХ РАСТИТЕЛЬНЫХ ЭКСТРАКTOB IN VITRO
}

\author{
Г. Р. Ламазян, И. Н. Сытник, П. А. Черновол, И. С. Чекман, Н. В. Хайтович \\ Национальный медицинский университет имени А. А. Богомольца
}

Резюме: исследована антиоксидантная активность (АОА) растительных экстрактов на модели ингибирования супероксид-радикала in vitro с модификациями. Оптическую плотность экстрактов, в их массовых концентрациях

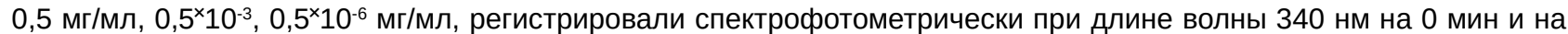
10 мин Экстракты Hypericum perforatum (L.) и Citrullus colocynthis (L.) Shrad. показали наличие АОА в диапазоне всех концентраций. На 10 мин значения АОА экстрактов уменьшалось приблизительно в 2 раза при концентрациях

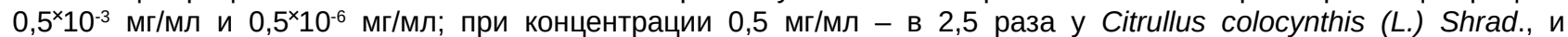
незначительное понижение значения AOA при этой же концентрации наблюдали у Hypericum perforatum (L.). AOA Hypericum perforatum (L.) повышалась с увеличением концентрации, в то время как для Citrullus colocynthis (L.) Shrad. прямопропорциональной зависимости «концентрация-активность» не отмечали, максимальную АОА последнего регистрировали при концентрации $0,5^{\times} 10^{-3} \mathrm{Mr} / \mathrm{M}$.

Ключевые слова: антиоксидантная активность, экстракты, Hypericum perforatum (L.), Citrullus colocynthis (L.) Shrad., активные фрормы кислорода, антиоксиданты.

\section{DETERMINATION OF ANTIOXIDANT ACTIVITY IN COLOR PLANT EXTRACTS IN VITRO}

\section{H. R. Lamazian, I. M. Sytnyk, P. A. Chernovol, I. S. Chekman, M. V. Khaitovych \\ National Medical University by O. O. Bohomolets}

Summary: the antioxidant activity (AOA) of plant extracts on the model of superoxide radical inhibition in vitro with modifications was investigated. Absorbance of extracts in their weight concentrations of $0.5 \mathrm{mg} / \mathrm{ml}, 0,5^{\times} 10^{-3}, 0,5^{\times} 10^{-6} \mathrm{mg} / \mathrm{ml}$ was recorded spectrophotometrically at $340 \mathrm{~nm}$ at $0 \mathrm{~min}$. and $10 \mathrm{~min}$. Extracts of Hypericum perforatum (L.) and Citrullus colocynthis (L.) Shrad. showed the presence of AOA in the range of all concentrations. At 10 min. AOA values of extracts decreased approximately twice at concentrations $0,5^{\times} 10^{-3} \mathrm{mg} / \mathrm{ml}$ and $0,5^{\times} 10^{-6} \mathrm{mg} / \mathrm{ml}$; at the concentration of $0.5 \mathrm{mg} / \mathrm{ml}-2.5$ times in Citrullus colocynthis (L.) Shrad., and a slight lowering of AOA values at the same concentration was observed in Hypericum perforatum (L.). AOA of Hypericum perforatum (L.) increased with rising of concentration, while for Citrullus colocynthis (L.) Shrad. direct proportional correlation «concentration-activity» was not mentioned, the maximum AOA for the last one was recorded at the concentration of $0,5^{\times} 10^{-3} \mathrm{mg} / \mathrm{ml}$.

Key words: antioxidant activity, extracts, Hypericum perforatum (L.), Citrullus colocynthis (L.) Shrad., reactive oxygen species, antioxidants. 